\title{
How Banks' Resources at the Retail Level Affect Their Output?
}

\author{
Seham ALOTHMAN ${ }^{1}$, Mohammed AL-MAHISH ${ }^{2}$
}

Received: September 10, 2020 Revised: November 02, 2020 Accepted: November 16, 2020

\begin{abstract}
The study aims to measure the productivity of the Saudi banking sector at the retail level using secondary data for 11 local banks from the period 2015-2019. The study uses an extended version of the Cobb-Douglas production function to account for the fact that as banks openup more retail branches, they will need to employ more labor. The extended Cobb-Douglas production function was estimated using the two-way fixed effect model to account for unobserved heterogeneity across Saudi banks resulting from differences in labor competencies and leadership style. Besides, the model accounts for unobserved heterogeneity among Saudi banks due to the advancement in electronic services over time. The results showed that labor, branches, customers' deposits, and fixed deposits have a positive effect on the total value of generated loans. Conversely, ATM has an insignificant effect on generated loans. The average scale elasticity shows that the Saudi banks at the retail level are operating under decreasing returns to scale. The average marginal rate of technical substitution shows that Saudi banks need at least one ATM to replace one unit of labor at the retail level while keeping the same level of output.
\end{abstract}

Keywords: Productivity, Retail Banking Sector, Saudi Banks, Cobb-Douglas Function

JEL Classification Code: D24, G21, G24, L25

\section{Introduction}

Productivity matters whether at the industrial level, the macroeconomic level, or the individual level. Efficient productivity increases profitability, decreases costs, supports investment decisions, increases its contribution to GDP, and thus supports the state's economy. Through productivity, we can evaluate the performance of banks and see whether they are efficiently using their inputs or not. (Knight, 1933) proposed that productivity should be redefined as the ratio of useful output to input (Fried \& Schmidt, 2013). The purpose of establishing banks in the first place is the economics of scale in providing funds because it enables individuals and

${ }^{1}$ First Author. Graduate Student, Department of Agribusiness and Consumer Science, College of Agriculture and Food Science, King Faisal University, Saudi Arabia. Email: salothman1991@gmail.com ${ }^{2}$ Corresponding Author. Assistant Professor, Department of Agribusiness and Consumer Science, College of Agriculture and Food Science, King Faisal University, Saudi Arabia [Postal Address: 31, Al-Hofuf, Eastern province, 31982, Saudi Arabia] Email: malmahish@kfu.edu.sa ; mohammed_9m@yahoo.com

(c) Copyright: The Author(s)

This is an Open Access article distributed under the terms of the Creative Commons Attribution Non-Commercial License (https://creativecommons.org/licenses/by-nc/4.0/) which permits unrestricted non-commercial use, distribution, and reproduction in any medium, provided the original work is properly cited. companies to protect their money at costs less than the costs of protecting it themselves. Banking services are not limited to providing storage facilities for funds only. Banks play a much larger role in the economy. Commercial banks charge interest for providing loans and credit services. Most Saudi banks operate according to Islamic financial principles, which differs from the conventional financial system since Islamic banks do not operate as a pure lender. Islamic banks must be directly involved in trade and investment operations and assume direct ownership of real estate assets. Most Islamic scholars prohibit debt trading (except at face value) and purchasing of debt-based credit risk instruments, in addition to selling or renting something that one does not own (Venardos, 2010). Financial and economic development go hand in hand. An economy that lacks financial institutions to effectively direct resources from savers to investors is unlikely to prosper.

The banking sector occupies an important place in the Saudi economy, as it is considered one of the largest services industry. The Saudi Hollande Bank was the first bank in the Kingdom of Saudi Arabia (KSA) in 1926, and had the name of the Dutch Trade Company. It was the only bank operating in KSA at that time. The bank played the role of the central bank and kept the kingdom's gold and financial reserves. In 2016, the bank changed its name to Alawwal bank. Also, in 2019 the bank merged with SABB Bank to achieve economies 
of scale (Alawwal, 2020). National Commercial Bank issued the first investment fund in the Kingdom in 1997 and then turned into a joint-stock company with the majority of stock owned by the government (National, 2020). Samba Financial Group opened its first branch in 1955 through Citibank in Jeddah (Samba, 2020). Riyad Bank started its activities in 1957 with a capital of approximately 30 billion riyals, and it owns 312 branches and more than 5,600 employees, with Saudi citizens constituting $93 \%$ of its labor force. This is considered the highest percentage of localization among financial institutions in KSA.

In 1957, the first branch of Al-Rajhi bank was opened in Riyadh, and it currently manages assets of more than 384 billion riyals (Al Rajhi, 2020). SABB bank, an affiliate of HSBC bank, started its actual activity in 1978 with a capital of approximately 100 million riyals. Then the bank doubled its capital to reach 20.5 billion Riyals. It is considered one of the first Saudi banks to issue credit cards (Sabb, 2020). The Banque Saudi Fransi was established in 1977 (Alfransi, 2020). The Saudi Investment Bank was established in 1976, and the bank participates in 3 Saudi companies: American Express Saudi Arabia, Saudi Orix Company for leasing and providing financial leasing services, Amlak International for Finance and Real Estate Development and MEDGULF (Investment, 2020). The Arab National Bank was established in 1979 as a listed Saudi joint-stock company (Arab, 2020). It employs 4,130 employees. Bank Al-Jazira was established in 1975 and started its first operations after it acquired branches of the National Bank of Pakistan (Aljazira, 2020). Alinma Bank was also established in 2006 and was listed on the Saudi stock exchange market in 2008 (Alinma, 2020). Bank Albilad was established in 2004. The bank recorded a net profit of more than one billion Riyals for the first time since its inception and won the best digital bank award in 2018 (Albilad, 2020).

Affana (2019) examined the merger of Saudi banks and its impact on the banking sector. The paper concluded that Saudi Arabia should implement policies and procedures that would enhance the potential mergers of domestic banks to improve their financial services and to make the sector more competitive than foreign banks. The statistical reports of the Saudi Arabian Monetary Agency (SAMA) confirmed that the Saudi banking sector continues to achieve good results in terms of profitability and financial solvency during the past years and until now (Authority, 2019). However, achieving high-profit rates does not necessarily imply efficient performance and the ability to efficiently manage the mix of inputs to obtain the highest possible output. Besides, it does not necessarily reflect the optimal use of resources and their preservation from waste. The banking industry aims to invest its inputs from deposits, physical assets, and human capital to provide the best services and attract the largest possible number of customers. This helps increase the volume of loans offered, whether at the retail or corporate level. The purpose of this research is to find out the contribution of Saudi banks' inputs at the retail level in terms of their impact on the value of generated loans. The study also aims to measure the performance of the Saudi banking sector at the retail level by estimating scale elasticity.

\section{Literature Review}

Barata (1987) presented the economic causes of the basic production function in the case of banks' operating costs, showing whether this function was Constant Elasticity of Substitution (CES) or Cobb-Douglas production function. The article presented empirical evidence for the Portuguese banking sector and the difference between the assumption of the Cobb-Douglas primary production function and the CES production function. Also, assuming banks maximize their financial margins (the bank's net production) instead of maximizing profits, the results showed that the CobbDouglas production function cannot be rejected by data. Char and Hopenhayn (1991) researched human capital, growth, and the spread of new technology. They also studied the characteristics of a stable economy. The research showed that technologies spread more quickly in high-grown economies, where the increase in the rate of technology arrival means an increase in the rate of spread.

Ben-jadeed and Molina (2004) studied electronic banking services in KSA in terms of their origin and development by taking Samba Financial Group as a case study. The study focused on how banks perform, how they provide electronic banking services, and how to improve their capabilities to create valuable and modern strategies. Case study methodology and reliance on network approaches are used to formulate the theoretical framework. The paper tried to answer several questions namely how electronic banking services were developed for banks, how coordination between demand and supply factors took place, and the role of electronic banking services in leading the strategic directions of banks. Al-jadeed (2005) studied strategies for establishing banking values for KSA's investment banks. This paper defined ways to create valuable e-business and focused on electronic banking services provided by banks to build their ability to compete and adopt new strategies. The study used a case study approach and a network approach for theoretical review. The paper attempted to answer the following questions: (1) How values are created in electronic banking services for banks, (2) How banks electronic banking capabilities are built, and (3) What is the role of electronic banking in shaping the direction of strategic plans for banks. The results indicated that the acceleration of differentiation and strategy building is linked to the development of electronic banking services. Al-Jarrah abd Molyneux (2006) examined cost efficiency using the random limits model to 
estimate cost-effectiveness and levels of efficiency on large scale banks in the Jordanian, Egyptian, Saudi, and Bahrain banking systems. The sample consisted of data on 82 banks operating in the countries under investigation from 19922000 . The results showed an average cost efficiency of about 95\% and Islamic banks were the most cost-effective while investment banks were the least expensive. Estimates of cost inefficiencies showed that the mentioned banks are $65 \%$ effective.

Awamleh and Fernandes (2006) examined the prevalence of online banking services among educated consumers in a high-income developing country outside the OECD. More specifically, the paper analyzed online banking channels and banking preferences in the United Arab Emirates (UAE). The study examined the factors affecting the intention to use online banking services and its continued use by both online and offline users. To achieve this goal, the study used a technology acceptance model (TAM). Data was collected from potential users, and a multiple regression analysis was performed. The study found that the relative benefits, perceived risks, and computer quality were the most influencing factors for the continued use of online banking services by users. However, the relative benefit and validity of the results were not important to non-users. Al-Somali et al. (2009) examined the acceptance of online banking services in KSA. The study aimed to identify factors that encourage customers to use online banking services in KSA. The study used the TAM model on a sample of 400 respondents. The study concluded that the quality of Internet use, awareness of the benefits of online banking services, social effect, and computer efficiency have a significant impact on perceived interest and flash usage. Education, trust, and resistance to change also support customers ' attitudes toward online banking.

Masood et al. (2009) examined common complementarity and causal relationship between return on assets (ROA) and return on equity (ROE) for Saudi banks to analyze the determinants of bank profitability in the KSA from 19992007. The long-term relationship between the variables and the time-series characteristics of the individual variables were examined by performing a stationary test using Augmented Dickey-Fuller (ADF). The relationship of dynamic integration in the short and long run was investigated using the Johansen multivariate co-integration test and the Granger causality test. During the study period, the relationship between ROA and ROE was examined, and experimental results had shown strong evidence that the variables were related in the long run. The results indicated that there was a long-term relationship between ROE and ROA. Granger causality test showed that there was only a one-way relationship between ROE and ROA.

Akhtar (2010) attempted to calculate the degrees of technical efficiency and productivity growth for banks in the KSA using the Data Envelopment Analysis (DEA) methodology. The results indicated that inefficiency stems from technical inefficiency in particular. The results of the Malmquist Productivity Index (MPI) showed a clear improvement in the average bank productivity. The main source of productivity growth was efficiency change relative to technological change. Also, banks in KSA succeeded in achieving the best performance because the average technical efficiency (TE) score exceeded the ideal levels. The results summarized that Saudi Arabia needs to accelerate and diversify more efforts to mobilize resources on a large scale, and this suggests that deposits are not the main source of resource mobilization. The study recommended that the current monopoly type of the banking sector must be transformed into a competitive sector by enabling banks to search for idealism and competitiveness at the same time.

Kumar et al. (2011) examined the prevalence of Automated Teller Machine (ATM) technology in Indian banks by analyzing ATM technology and its rate of substitution with human tellers. The study used constant elasticity of substitution (CES) production function, where the degree of replacement can be estimated. The estimation results showed that the degree of substitution is high. The study concluded that the decrease in ATMs' prices and the increase in labors' wage rates contributed to the deployment of the ATMs. Ershaid (2017) conducted a study to reveal the impact of investment in information technology on the performance of Saudi banks listed on the Saudi stock exchange market during the period 2006-2012. The performance measures used in the study include ROA and ROE. The study found a positive impact of investing in information technology on the performance of the Saudi banks. The study recommended the necessity of intensifying investment operations in the field of information technology to improve services and enhance financial performance.

Hassan et al. (2018) examined the relative efficiency of Islamic banks in KSA. The study used deposits, assets, and capital as inputs to measure banks' performance by applying DEA methodology. The data was panel data covering the period between 2008-2016. The study was limited to Islamic banks only. The main results indicated that Al-Rajhi is the most efficient bank in terms of technical efficiency followed by Bank Al-Jazira, while Al-Inma and Al-Bilad are in third and fourth places, respectively. However, the technical and scale efficiency of Al-Rajhi Bank began to decline after 2012, which indicated the possibility to provide an opportunity for improvement in management. On the other hand, Bank AlBilad, which is a relatively small bank compared to the size of Al Rajhi Bank, had shown excellent results in terms of volume efficiency.

Alwabeel (2019) measured the efficiency of banks in the Saudi banking sector using the DEA method in both the input and output sides under the assumption of constant 
returns to scale (CRS) and variable returns to scale (VRS) during the period 2013-2017. The study sample comprised banks listed on the Saudi stock exchange market. The study concluded that there is a surplus of resources available to inefficient banks, which means the resources of these banks exceed their use. The study found that SABB, Arab National Bank, Al-Inma Bank, and Bank Al-Jazira achieved degrees of relative efficiency indicating their ability to achieve optimal use of the resources available to them. On the other hand, Samba Financial Group, Riyad Bank, Alawwal Bank, and Bank Albilad can achieve relative efficiency by reducing their outputs and inputs.

Yusuf (2019) conducted a study to compare the performance of Islamic banks and traditional banks in KSA using a sample consisting of 10 Islamic banks and 10 traditional banks during the period from 2008 to 2017. The study used financial analysis (indicators and financial ratios), liquidity ratios, and profitability ratios. The t-test results revealed that the ability of Islamic banks to make profits is quite parallel to conventional banks, but the volume of Islamic banking activity is greater than conventional banks. The results also showed that traditional banks outperform Islamic banks in terms of liquidity. The study recommended the need for Islamic banks to increase their size quickly to fulfill their obligations by directing their money in a shortterm investment, maintaining their profits, employing financial assets effectively, and working to enhance their competitive capabilities in the face of competitors from traditional banks.

In 2008, the Indonesian authority issued a decree requiring Islamic banks to manage resources in financial and social funds at the same time. Therefore, Usman et al. (2019) examined whether there is an impact of this decision on the productivity of social funds and financial funds of Islamic banks in Indonesia by using the Malmquist Productivity Index (MPI). The study concluded that social funds are more productive than financial funds, and social funds advanced by $8.2 \%$ while financial funds declined by $5.4 \%$. Also, the change in the productivity of Islamic banks was found to be affected by the technology side rather than the efficiency side.

Le and Ngo (2020) research focused on the determinants of bank profitability to provide evidence about the factors that affect the profitability of banks based on national statistical data for 23 countries during the period 2002-2016. The paper used the generalized method of moments (GMM) estimator method to control for heterogeneity. The results indicated that electronic banking services, the number of banks' cards, the number of ATMs, and the number of points of sales (POS) can improve the profitability of banks. The study recommended the need to expand electronic banking services. In this study, we test the productivity of the Saudi banks at the retail level and its impact on the value of generated loans in an attempt to examine their efficiency in exploiting their resources at the retail level. Also, the paper aims to estimate the marginal rate of technical substitution between ATMs and labor at the retail level.

Habtoor (2020) examined the concentration of ownership in influencing the relationship between the composition of the board of directors and the performance of Saudi banks. The sample of the study consisted of Saudi banks listed on the stock market during the period 2011-2018. The results showed a significant negative moderating effect of the ownership focus on the association between the composition of the board of directors and the performance of the bank. The composition of the board of directors as independent board members, executive board members, and nonexecutive board members in banks with a high concentration of ownership will have a weak positive impact on banks' performance. The indicators of the financial soundness of the banking sector are capital, asset quality, management, profits, liquidity, and sensitivity to market trend, and the dynamic regression panel was used to determine the effects of each factor on banks' lending growth in Vietnam during the period 2007-2019. The paper concluded that large capital reserves, high asset quality, and liquidity contributed positively to the increase in loan growth. The less efficiently managed banks may adopt a strong lending strategy, and the more profitable banks have the potential to expand their lending activities to a greater extent. Conversely, the perceived interest rate risks led to holding back loan growth for banks' sensitivity to interest rate changes (Nguyen \& Dang, 2020). Kumar et al. (2020) tested the efficiency of the Indian private banking sector using the DEA approach from 2005-2017. The results showed that $59.9 \%$ of banks operate at more than 0.9 level of proficiency.

\section{Research Methods and Materials}

Economic theory largely revolves around money, costs, prices, markets, return on investment, profits, and similar economic concepts. Often changes in production are compared to changes in factor consumption such that if output increases more than input usage, it is referred to as increasing returns to scale. The concept of marginal product of an input is also used to refer to the additional increase in output resulting from an additional unit of input, which is considered as the slope of the production function. The elasticity of a factor of production shows the percentage changes in output resulting from a $1 \%$ change in the input (Rasmussen, 2013). The Cobb-Douglas production function is widely used to describe production functions in both agriculture and industry. This functional form requires many strict assumptions. The first assumption is that the expansion path is linear. The Cobb-Douglas production function is a homogeneous function with a degree of homogeneity $n$ equal to the sum of the exponents $B_{1}$ and $B_{2}$ (Rasmussen, 2013). 
The Cobb-Douglas production function can be expressed in its general form as follows:

$$
Y_{i}=B_{0} K^{\mathrm{B} 1} L^{\mathrm{B} 2}
$$

To convert the nonlinear relationship between output and inputs into estimable linear form, we use natural logarithm as below:

$$
\log Y_{i}=\log B_{0}+\mathrm{B}_{1} \log K+\mathrm{B}_{2} \log L+e_{i}
$$

Where $\mathrm{Y}$ is output, $\mathrm{k}$ is capital, and $\mathrm{L}$ is labor. The betas are parameters to be estimated and $e_{i}$ is the error term. Therefore, in this study, we will use the linearized version of the Cobb-Douglas production function to reveal the effect of banks' input at the retail levels on the value of banks generated loans as a proxy for output. The study uses several inputs namely the number of employees, the number of branches, the number of ATMs, customer deposits, and fixed deposits. The model can be expressed using the fixed-effect model as below:

$$
\begin{aligned}
\log Y_{i}= & a_{0}+B_{1} \log X_{1 i t}+B_{2} \log X_{2 i t}+B_{3} \log X_{3 i t} \\
& +B_{4} \log X_{4 i t}+B_{5} \log X_{5 i t}+u_{i t}
\end{aligned}
$$

Where

$Y=$ Total loans

$X_{1}=$ Number of Labors

$X_{2}=$ Number of ATMs

$X_{3}=$ Number of branches

$X_{4}=$ Fixed deposits

$X_{5}=$ Customer deposits

$u_{i}=$ disturbance term

$a_{i}=\beta_{0}+\beta_{6} Z_{i}$

$a_{0}$ is entity fixed effect term and $Z_{i}$ is a term that varies across banks but not over time. B1 is the (partial) elasticity of production with respect to inputs, that is, it measures the percentage change in output resulting from a $1 \%$ change in inputs, holding other variables constant (Gujarati, 2004). The sum $\left(B_{1}+B_{2}+B_{3}+B_{4}+B_{5}\right)$ gives information about returns to scale, that is, the output response to the relative change in the inputs. If the result is equal to 1 , then there are constant returns to scale, which means doubling the inputs will lead to a doubling of the output. If the total is less than 1 , then there is diminishing returns to scale, meaning that the doubling of the inputs will be less than the output. Also, if the sum is greater than 1 , then there is increasing returns to scale, which indicates that the amount of output we obtain is bigger than the amount of input we insert.

One main benefit of using the fixed-effect model is that it helps us to control unobserved heterogeneity among Saudi banks. The variation in banks that comes from omitted variables such as differences in leadership or management style is expressed by the variable $\mathrm{Z}$ (Croissant \& Millo, 2019). The fixed-effect regression model in equation (3) contains an entity fixed-effect. However, the fixed-effect model can contain time fixedeffect. In this case, the fixed-effect model is known as time fixed-effect, and will be constant across banks but vary across time. The time fixed-effect model helps us control unobserved heterogeneity due to the advancement in banks' technology that evolves over time to facilitate bank transactions at the retail level. Furthermore, the fixed-effect model can contain both an entity fixed-effect and time fixed-effect and, in this case, it is called a twoway fixed effect (Stock \& Watson, 2012).

Moreover, the random-effect model assumes that the unobserved effect, $a_{i}$, is uncorrelated with the independent variables (Wooldridge, 2013).

Since the data is panel data, we will conduct Hausman's test to help us chose between a random effect or fixed-effect model as the appropriate model. The null and alternative hypothesis of this test is as below:

$H_{0}$ : the random-effect estimator is indeed efficient and consistent.

$H_{1}$ : the fixed-effect estimator is the appropriate estimator.

Considering the fact that the more banks open-up branches the more they will hire labor, we extend equation (3) by adding an interaction term to account for this fact.

$$
\begin{aligned}
\log Y_{i t}= & a_{i}+B_{1} \log X_{1 i t}+B_{2} \log X_{2 i t}+B_{3} \log X_{3 i t} \\
& +B_{4} \log X_{4 i t}+B_{5} \log X_{5 i t}+I_{1}\left(\log X_{1}\right)\left(\log X_{3}\right)+u_{i}
\end{aligned}
$$

Where $I\left(\log X_{1}\right)\left(\log X_{3}\right)$ is the interaction term. Furthermore, the marginal elasticity (ME) of input is computed as below:

$$
M E_{i}=\left(\partial \log Y_{i t} / \partial \log X_{i t}\right)
$$

The data for this paper is secondary data consisting of Saudi banks listed on the main market of the Saudi stock exchange (Tadawul, 2019). The data is panel data that comprise 11 banks. The data was collected through banks' reports, detailed financial statements, and the Saudi Arabia Monetary Agency (SAMA) website. The total number of observations equals 55 covering the period 2015-2019. Table 1 shows descriptive statistics of the collected data. Using panel data has some advantages such as more variance, less collinearity among variables, increase in degrees of freedom, and hence it helps in obtaining an efficient model (Gujarati, 2004). 
Table 1: Descriptive Statistics of Saudi Banks Data

\begin{tabular}{|l|c|c|c|c|c|c|c|}
\hline Statement & N & Mean & St dev & Median & Min & Max & SE Mean \\
\hline Total loans & 55 & 1234 & 6871 & 1188 & 3425 & 2823 & 9264 \\
\hline Number of labors & 55 & 5231 & 3835 & 3884 & 1481 & 1368 & 517.1 \\
\hline Customer deposits & 55 & 1424 & 8798 & 1406 & 1351 & 3534 & 1186 \\
\hline Fixed deposits & 55 & 4854 & 2134 & 4987 & 1039 & 9016 & 2878 \\
\hline Number of branches & 55 & 179.4 & 158 & 90 & 48 & 554 & 21.29 \\
\hline Number of ATMs & 55 & 1611 & 1370 & 971 & 469 & 5215 & 185 \\
\hline
\end{tabular}

\section{Results and Discussion}

We estimated the Cobb-Douglas production function (3) and equation (4) that includes the interaction term by using $\mathrm{R}$ software, and the results are shown in Table 2 . The results of the Hausman test show that the appropriate model is the fixed-effect model at a $1 \%$ significance level. We, therefore, reject the null hypothesis that the appropriate model is the random-effect estimator and accept the alternative hypothesis that a suitable model is the fixed-effect estimator. Thus, we estimated a two-way fixed-effect model to control for unobserved heterogeneity resulting from differences across Saudi banks and advancement in banks' technology at the retail level over time.

The value of F-statistics shows that the model is significant at a $1 \%$ level. The coefficient of determination value $\left(R^{2}\right)$ is equal to 0.60 for the homogeneous production function model, and 0.72 for model (4) that includes the interaction term. This shows that model (4) is a better fit than model (3) and explains more of the variation in the dependent variable than model (3). More specifically, $72 \%$ of the variations in the value of Saudi banks' generated loans are explained by model (4) independent variables. Furthermore, we estimated model (4) with clustered standard error, and we notice that the failure to use clustered standard error can give us an incorrect conclusion that consumer deposits do not affect the value of generated loans, which does not make sense. Moreover, after using clustered standard error, we notice that the $\log$ of customer deposits has become significant. Therefore, we use the two-way fixed-effect model with the interaction term and clustered standard error in computing marginal elasticities of inputs.

The average marginal elasticity of labor is 0.57 indicating that a $1 \%$ increase in labor increases the value of generated loans by $0.57 \%$. Conversely, the results show that ATM does not contribute significantly to increasing the value of bank loans. Banks' branches have a positive effect on the value of generated loans, however, the average marginal elasticity of branches is -0.20 revealing that a $1 \%$ increase in the number of branches decreases the value of generated loans by $0.20 \%$. Nonetheless, this result does not apply to all Saudi banks. Table 3 shows the average marginal elasticity of bank branches for all the banks in the sample.

We notice in Table 3 that among the 11 banks in our sample, only 3 (Al-Inma Bank, Bank Aljazira, and Saudi Investment Bank) have positive average marginal elasticity of branches. As a result, those 3 banks should build more branches until they reach the point where adding more branches do not contribute significantly to their outputs.

The average marginal elasticity of fixed deposits is 0.19 showing that a $1 \%$ increase in fixed deposits increases the value of generated loans by $0.19 \%$. Besides, the average marginal elasticity of customers' deposits is 0.03 indicating that a $1 \%$ increase in customers' deposits increases the value of generated loans by $0.03 \%$. The average return to scale elasticity is 0.74 showing that Saudi banks at the retail level, on average, are operating under decreasing returns to scale. However, the disaggregate analysis in Table 3 shows that Samba bank, Alinma Bank, Bank AlJazira, Saudi Investment Bank, and Saudi French bank are enjoying increasing returns to scale at the retail level. Moreover, SABB bank is almost working under constant returns to scale. Besides, we calculate the marginal rate of technical substitution between labor and ATM as below:

$$
M R T S=\left(\frac{\text { marginal productivity of labor }}{\text { marginal productivity of ATMS }}\right)
$$

MRTS shows the number of ATMs that are required to substitute for one unit of labor if a bank wants to maintain the same level of loans. The average aggregate MRTS across the Saudi banks is 1.13 showing that they need to add 1.13 ATMs to replace one unit of labor at the retail level. 
Table 2: Regression Results \& Hausman Test

\begin{tabular}{|c|c|c|c|c|c|c|}
\hline \multicolumn{7}{|c|}{ Dependent variable } \\
\hline \multicolumn{7}{|c|}{ Total loans value } \\
\hline The model & \multicolumn{3}{|c|}{ Two-Way Fixed-Effect Model } & \multicolumn{3}{|c|}{ Estimated Random-Effect Model } \\
\hline $\begin{array}{l}\text { Independent } \\
\text { variables }\end{array}$ & Basic model & $\begin{array}{c}\text { With } \\
\text { Interaction }\end{array}$ & $\begin{array}{c}\text { Interaction\& } \\
\text { cluttered } \\
\text { standard error }\end{array}$ & Basic model & $\begin{array}{c}\text { With } \\
\text { Interaction }\end{array}$ & $\begin{array}{l}\text { Interaction \& } \\
\text { cluttered } \\
\text { standard } \\
\text { error }\end{array}$ \\
\hline $\begin{array}{l}\text { Number of } \\
\text { labors }\end{array}$ & $\begin{array}{c}0.570^{* * *} \\
(0.190)\end{array}$ & $\begin{array}{c}2.862^{* * *} \\
(0.614)\end{array}$ & $\begin{array}{c}2.862^{* * *} \\
(0.829)\end{array}$ & $\begin{array}{c}0.564^{* * *} \\
(0.180)\end{array}$ & $\begin{array}{l}1.266^{* *} \\
(0.568)\end{array}$ & $\begin{array}{c}1.266 \\
(0.733) \\
\end{array}$ \\
\hline $\begin{array}{l}\text { Number of } \\
\text { ATMs }\end{array}$ & $\begin{array}{c}0.069 \\
(0.247)\end{array}$ & $\begin{array}{c}0.152 \\
(0.210)\end{array}$ & $\begin{array}{c}0.152 \\
(0.192)\end{array}$ & $\begin{array}{c}0.113 \\
(0.180)\end{array}$ & $\begin{array}{c}0.161 \\
(0.192)\end{array}$ & $\begin{array}{c}0.160 \\
(0.158)\end{array}$ \\
\hline $\begin{array}{l}\text { Number of } \\
\text { branches }\end{array}$ & $\begin{array}{l}-0.100 \\
(0.226) \\
\end{array}$ & $\begin{array}{l}3.722^{* * *} \\
(1.007)\end{array}$ & $\begin{array}{l}3.722^{* *} \\
(1.390) \\
\end{array}$ & $\begin{array}{l}-0.006 \\
(0.202) \\
\end{array}$ & $\begin{array}{c}1.226 \\
(0.934) \\
\end{array}$ & $\begin{array}{c}1.225 \\
(1.231) \\
\end{array}$ \\
\hline Fixed deposits & $\begin{array}{c}0.208^{* * *} \\
(0.056)\end{array}$ & $\begin{array}{c}0.194^{* * *} \\
(0.048)\end{array}$ & $\begin{array}{l}0.194^{* *} \\
(0.073)\end{array}$ & $\begin{array}{l}0.301^{* * *} \\
(0.050)\end{array}$ & $\begin{array}{c}0.288^{* * *} \\
(0.049)\end{array}$ & $\begin{array}{l}0.288^{* *} \\
(0.083)\end{array}$ \\
\hline $\begin{array}{l}\text { Customer } \\
\text { deposits }\end{array}$ & $\begin{array}{l}0.047^{* *} \\
(0.022)\end{array}$ & $\begin{array}{c}0.033 \\
(0.019) \\
\end{array}$ & $\begin{array}{l}0.030^{* *} \\
(0.012)\end{array}$ & $\begin{array}{l}0.057^{* *} \\
(0.023)\end{array}$ & $\begin{array}{l}0.047^{* *} \\
(0.023)\end{array}$ & $\begin{array}{c}0.047 \\
(0.023) \\
\end{array}$ \\
\hline Interaction & & $\begin{array}{c}-0.470^{* * *} \\
(0.121)\end{array}$ & $\begin{array}{c}-0.470^{* * *} \\
(0.160)\end{array}$ & & $\begin{array}{l}-0.147 \\
(0.111) \\
\end{array}$ & $\begin{array}{l}-0.146 \\
(0.139)\end{array}$ \\
\hline Constant & & & & $\begin{array}{c}6.648^{* * *} \\
(1.092)\end{array}$ & $\begin{array}{c}0.888 \\
(4.653) \\
\end{array}$ & $\begin{array}{c}0.888 \\
(5.626) \\
\end{array}$ \\
\hline Observations & 55 & 55 & 55 & 55 & 55 & 55 \\
\hline $\mathrm{R} 2$ & 0.60 & 0.72 & 0.72 & 0.751 & 0.746 & 0.746 \\
\hline Adjusted R2 & 0.38 & 0.56 & 0.56 & 0.725 & 0.714 & 0.714 \\
\hline F Statistic & $10.353^{* * *}$ & $14.558^{* * *}$ & $14.558^{* * *}$ & $147.586^{* * *}$ & $40.834^{* * *}$ & $40.834^{* * *}$ \\
\hline Hausman Test & & & $\begin{array}{l}=106.2, \mathrm{df}= \\
\text { hypothesis: }\end{array}$ & $\begin{array}{l}\text { alue }<2.2 \mathrm{e}-1 \\
\text { odel is incons }\end{array}$ & & \\
\hline
\end{tabular}

Note: ${ }^{* * *},{ }^{* *}$ and ${ }^{*}$ indicates significant at $1 \%, 5 \%$ and $10 \%$ level of significance based on t-statistics.

Table 3: Average Marginal Elasticity of Branches across Saudi Banks

\begin{tabular}{|l|c|c|c|}
\hline Bank Name & $\begin{array}{c}\text { Average Labor } \\
\text { Elasticity }\end{array}$ & Average Branch Elasticity & Average Scale Elasticity \\
\hline AlRajhi Bank & -0.09 & -0.72 & -0.45 \\
\hline Riyad Bank & 0.15 & -0.38 & 0.14 \\
\hline Al-Ahli Bank & 0.05 & -0.72 & -0.29 \\
\hline Samba Bank & 0.85 & -0.14 & 1.08 \\
\hline Al-Inma Bank & 0.79 & 0.09 & 1.26 \\
\hline SABB Bank & 0.76 & -0.21 & 0.92 \\
\hline Bank AlJazira & 0.81 & 0.08 & 1.27 \\
\hline Bank Albilad & 0.64 & -0.18 & 0.83 \\
\hline Arab National Bank & 0.52 & -0.21 & 0.68 \\
\hline Saudi Investment Bank & 1.2 & 0.24 & 1.65 \\
\hline Saudi French Bank & 0.77 & -0.06 & 1.09 \\
\hline
\end{tabular}




\section{Conclusions}

The banking sector occupies a large position in most economies due to its significant role in financing investments and supporting economic growth. This paper studies the productivity of the Saudi banking sector by focusing on the retail level. The paper uses an extended version of the CobbDouglas production function to examine how banks inputs at the retail level (number of employees, number of branches, number of ATMs, fixed deposits, and customer deposits) affect their output as measured by the value of generated loans using panel data models. The extended Cobb-Douglas production function accounts for the fact that the more banks open-up retail branches, the more they employ labor.

Hausman test indicates that the appropriate model is a fixed-effect model. Estimation results of input elasticities show that a $1 \%$ increase in labor increases the value of generated loans by $0.57 \%$. Also, the average marginal elasticities of bank branches were mixed, i.e. increase in the number of branches for some banks have a positive impact on banks' loans, especially for emerging banks, while for other banks the increase in the number of branches has a negative impact on banks' loans. This can be attributed to unobserved factors such as quality of customer services, quality of banks' electronic services, skills, and competency of banks' labor force. Furthermore, the average marginal elasticity of fixed deposits and customers' deposits show that a $1 \%$ increase in fixed deposits and customers' deposits increases the value of banks' generated loans by $0.194 \%$ and $0.030 \%$, respectively. The average aggregate scale elasticity shows that Saudi banks are operating under decreasing returns to scale at the retail level. This fact justifies the merger in the Saudi banking sector between Alawal bank and SABB bank in late 2019. Also, Samba bank and AlAhli bank have announced their intention to merge in 2020. Finally, the paper calculates the marginal rate of technical substitution, and the result revealed that Saudi banks on average need at least one ATM to replace one unit of labor.

\section{References}

Affana. (2019). The merger of Saudi banks and its role in developing the banking sector: A case study of the merger of Alawwal Bank and SABB Bank. Global Journal of Economics and Business, 7(3), 243-257.

Akhtar, M. (2010). Are Saudi banks productive and efficient? International Journal of Islamic and Middle Eastern Finance and Management, 3(2), 95-112. https://doi. org/10.1108/17538391011054354

Al-jadeed, M. (2005). E-banking value creation strategies: The case of the Saudi investment bank. In IADIS International Conference on WWW/Internet 2005, Lisbon, Portugal, 19-22 October 2005, 118-129. http://www.iadis.org/icwi2005
Al-Jarrah, I., \& Molyneux, P. (2006). Cost efficiency, scale elasticity, and scale economies in Arab banking. Banks and Bank Systems, 1(3), 60-89.

Al-Somali, S. A., Gholami, R., \& Clegg, B. (2009). An investigation into the acceptance of online banking in Saudi Arabia. Technovation, 29(2), 130-141. https://doi.org/10.1016/j. technovation.2008.07.004

Al Rajhi. (2020). About Al Rajhi, Riyadh, Saudi Arabia: AlRajihibank. Retrieved from https://www.alrajhibank.com.sa/ alrajhi-group/about/who-we-are?\#

Alawwal. (2020). About Alawwal bank, Riyadh, Saudi Arabia: Alawwal. Retrieved from https:/www.alawwalbank.com/ar/ about-us/history

Albilad. (2020). About Albilad bank, Riyadh, Saudi Arabia: Bankalbilad. Retrieved September 8, 2020. https://www. bankalbilad.com/ar/personal/Pages/home.aspx

Alfransi. (2020). About Alfransi bank, Riyadh, Saudi Arabia: Alfransi. Retrieved from https://www.alfransi.com.sa/arabic/ the-bank/profile

Alinma. (2020). About Alinma Bank, Riyadh, Saudi Arabia: Alinma. Retrieved from https:/www.alinma.com/wps/portal/alinma

Aljazira. (2020). About Aljazira bank, Jeddah, Saudi Arabia: $B A J$. Retrieved from. https://www.baj.com.sa/ar-sa/About-Us/ Corporate-Profile

Alwabeel. (2019). Measuring the efficiency of banks in the Saudi banking sector using data envelope analysis during the period 2013-2017. Global Journal of Economics and Business, 6(2) 238-255. https://doi.org/10.31559/gjeb2019.6.2.1

Arab. (2020). About ANB bank, Riyadh, Saudi Arabia: Alfransi. Retrieved from https://onlinebanking.anb.com.sa/RetailBank/ app/logon.jsp?englang=en_AR

Authority, S. A. M. (2019). Annual statistics. Annual statistics. Riyadh, Saudi Arabia: SAMA. Retrieved from http://www. sama.gov.sa/ar-sa/EconomicReports/AnnualReport/Annual_ Report_55th-AR.pdf

Awamleh, R., \& Fernandes, C. (2006). Diffusion of Internet banking amongst educated consumers in a high-income nonOECD country. Journal of Internet Banking and Commerce, 11(3), 1-17. http://www.arraydev.com/commerce/jibc/

Barata, J. (1987). Modeling bank operating costs with an underlying CES production function. Estudos de Economia, VII(2), 99118.

Ben-jadeed, M., \& Molina, A. (2004). The emergence and evolution of e-banking in Saudi Arabia: The case of Samba Financial Group. Frontiers of E-Business Research, August, 90-106. https://www.researchgate.net/profile/Alfonso_Molina/ publication/228762232_The_Emergence_and_Evolution of e-Banking in Saudi Arabia The Case of Samba Financial_Group/links/00b $\overline{7}$ d5285f0 $554 \mathrm{~b} 137000000$.pdf

Char, V. V., \& Hopenhayn, H. (1991). Vintage human capital, growth, and the diffusion of new technology. Journal of Political Economy, 99, 1143-1165. 
Croissant, Y., \& Millo, G. (2019). Panel data econometrics with R (1st ed). NJ, USA: Wiley Publishing Company. https://doi. org/10.1002/9781119504641

Ershaid, O. N. (2017). The impact of investment in information technology on the performance of Saudi banks. The Arab Journal of Management, 37(1), 207-223.

Fried, H. O., \& Schmidt, S. S. (2013). Efficiency and productivity. Etica e Politica, 15(1). https://doi.org/10.1093/acprof

Gujarati, D. N. (2004). Basic econometrics (4th ed). Pennsylvania, USA: The McGraw-Hill Companies. https://doi.org/10.1126/ science. 186874

Habtoor, O. S. (2020). The moderating role of ownership concentration on the relationship between board composition and Saudi bank performance. Journal of Asian Finance, Economics, and Business, 7(10), 675-685. https://doi. org/10.13106/jafeb.2020.vol7.no10.675

Hassan, M. U., Khan, M. N., Amin, M. F., \& Khokhar, I. (2018). Measuring the performance of Islamic banks in Saudi Arabia. International Journal of Economics and Management, 12(1) 99-115.

Investment. (2020). About the Bank. Riyadh, Saudi Arabia: SAIB. Retrieved September 8, 2020. https://www.saib.com.sa/ar

Knight, F. (1933). Capitalistic production, time, and the rate of return. In F. Knight, Economic essays in honor of Gustav Cassel (pp. 327-342). London: George Allen \& Unwin Limited

Kumar, A., Anand, N., \& Batra, V. (2020). Trends in Indian private sector bank efficiency : Non-Stochastic Frontier DEA Window analysis approach. Journal of Asian Finance, Economics, and Business, 7(10), 729-740. https://doi.org/10.13106/jafeb.2020. vol7.n10.729

Kumar, L., Malathy, D., \& Ganesh, L. S. (2011). The diffusion ofATM technology in Indian banking. Journal of Economic Studies, 38(4), 483-500. https://doi.org/10.1108/01443581111160905

Le, T. D., \& Ngo, T. (2020). The determinants of bank profitability: A cross-country analysis. Central Bank Review, 20, 65-73. https://doi.org/10.1016/j.cbrev.2020.04.001

Masood, O., Aktan, B., \& Chaudhary, S. (2009). An empirical study on banks' profitability in the KSA: A co-integration approach.
African Journal of Business Management, 3(8), 374-382. https://doi.org/10.5897/AJBM09.112

National. (2020). About the bank. Saudi Arabia: NCB. Retrieved from. https://www.alahli.com/ar-sa/about-us/Pages/default.aspx

Nguyen, H. D. H., \& Dang, V. D. (2020). Bank-specific determinants of loan growth in Vietnam: Evidence from the CAMELS approach. Journal of Asian Finance, Economics, and Business, 7(9), 179-189. https://doi.org/10.13106/jafeb.2020. vol7.no9.179

Rasmussen, S. (2013). Production economics the basic theory of production optimization (2nd ed.). Berlin-Heidelberg: Springer

Sabb. (2020). About Sabb bank, Riyadh, Saudi Arabia: SABB. Retrieved from https://www.sabb.com/en/

Samba. (2020). About Samba, Riyadh, Saudi Arabia: Samba. Retrieved from https://www.samba.com/ar/about-us/our-group/ history.aspx

Stock, J. H., \& Watson, M. W. (2012). Introduction to Econometrics (3rd ed.). Boston: Pearsons.

Tadawul. (2019). Detailed annual reports and data for banks. Retrieved July 30, 2020. https://www.tadawul.com.sa/wps/ portal $/$ tadawul $/$ home?locale $=$ en

Usman, N., Andriyani, L., \& Pambuko, Z. B. (2019). The productivity of Islamic banks in Indonesia: Social funds versus financial funds. Journal of Asian Finance, Economics, and Business, 6(3), 115-122. https://doi.org/10.13106/jafeb.2019. vol6.no3.115

Venardos, A. M. (2010). Current issues in Islamic banking and finance: Resilience and stability in the present system. In A. M. Venardos, Current issues in Islamic banking and finance resilience and stability in the present system (pp. 1-17). Singapore: World Scientific Publishing. https://doi. org/10.1142/6979

Wooldridge, J. M. (2013). Introductory econometrics : A modern approach (7th ed). Boston, MA: Cengage

Yusuf. (2019). Comparison of the performance of Islamic and conventional banks in the Kingdom of Saudi Arabia during the period 2008-2017. Zarqa Journal for Research and Human Studies, 19(3), 295-312. 